Revue européenne des sciences sociales

European Journal of Social Sciences

XLIV-134 | 2006

Quel(s) défi(s) pour les sciences sociales à l'heure de la mondialisation?

\title{
The market, mind and rationality. From Vienna to Paris and back
}

\section{Abraham Rotstein}

\section{CpenEdition}

\section{Journals}

Electronic version

URL: http://journals.openedition.org/ress/310

DOI: $10.4000 /$ ress.310

ISSN: $1663-4446$

\section{Publisher}

Librairie Droz

\section{Printed version}

Date of publication: 1 June 2006

Number of pages: $259-269$

ISBN: 9-782-600-01095-5

ISSN: 0048-8046

Electronic reference

Abraham Rotstein, «The market, mind and rationality. From Vienna to Paris and back », Revue européenne des sciences sociales [Online], XLIV-134 | 2006, Online since 15 October 2009, connection on 01 May 2019. URL : http://journals.openedition.org/ress/310 ; DOI : 10.4000/ress.310 
Abraham ROTSTEIN

\section{THE MARKET, MIND AND RATIONALITY. FROM VIENNA TO PARIS AND BACK}

The mention of the great city of Vienna conjures up the many legacies of music, art and philosophy which it nurtured ${ }^{1}$. But as important as any of these is the more prosaic legacy of the Austrian economists ranging from $\mathrm{C}$. Menger to F. von Hayek. And for some, Vienna may conjure up as well, the debate that K. Polanyi had with these economists in the 1920s. ${ }^{2}$

However paradoxical it may seem, it was by virtue of this debate, carried on directly and indirectly over a lifetime, that Polanyi was first and foremost an Austrian, or rather an Austrian «in mirror image». This was true not only by virtue of the years of his life and his work in Vienna, but more so because he was drawn into and remained a protagonist in the debate around the fundamental issues first raised by the Austrian economists. Menger and his followers E. von Bohm-Bawerk, and L. von Mises had established and diligently pursued much of the agenda of the debate. F. von Hayek was the important representative of this school in recent decades.

The particular topic launched by von Mises in 1920 was whether a socialist economy was at all viable without the direction provided by market prices. Regulated or administered prices were bound to lead to economic confusion and the misallocation of resources he maintained.

I am indebted to Gérald Berthoud with whom I have had extensive discussions on these matters. Our joint paper «The Seductive Market» was presented at the Third International Conference of the Karl Polanyi Institute of Political Economy in Milan, November 1990, and was published in Michele Cangiani (ed.), The Milano Papers, Essays in Social Alternatives, Montreal, Black Rose Books, 1997. Earlier versions of these ideas may be found in my paper «Deconstructing the Market: Some Preliminary Considerations » presented at the second International Conference of the Polanyi Institute in 1988 and also in the Fifth International Conference in Vienna in November 1994 under the present title.

L. Von Mises' article that initiated the debate was «Die Wirtschaftsrechnung im Sozialistischen Gemein Wesen», Archiv für Sozialwissenschaften, 47, 1920. The response was given by K. Polanyi, «Sozialistische Rechnungslegung», Archiv für Sozialwissenschaft und Sozialpolitik, 49, Pt2, 1922; «Die Funktionelle Theorie der Gesellschaft un das Problem der Sozialistischen Rechnungslegung», ibid, 52, 1924; «Neue Erwagungen zu unserer Theorie von Praxis », Der Kampf, January 1922, p. 18-24. Translations of these latter two articles by K. Polanyi-Levitt appeared in Cahiers monnaie et financement, $\mathrm{n}^{\circ}-22$, 1994, p. 115-126 and 127-137. See also the excellent article on this topic by M. Mendell, «Karl Polanyi and Feasible Socialism», in K. Polanyi-Levitt (ed.), The Life and Work of Karl Polanyi, Montreal, Black Rose Books, 1990, p. 66-77. 
We must however bypass the immediate issues of this topic and look to the wider scope of the debate that ensued about the human economy. As Lee Congdon remarked, Polanyi «was less interested in joining the Austro-Marxists than he was in meeting the challenge presented by the so-called Austrian school of economics $»^{3}$.

There was in fact, much more to Polanyi's intellectual career than these themes in economics. The exposition of his philosophical ideas such as «the reality of society » went far beyond the issues in either economics or economic history. Yet one might say that the entire corpus of Polanyi's work in general economic history and in economic anthropology was governed to a major extent by the theoretical challenge presented by the Austrian school. For example, the subsequent title of Polanyi's Columbia research project of 1957, «The Origins of Economic Institutions », could just as well have been a congenial title for the work being done by von Mises and his colleagues. Polanyi's answers to these questions were of course, diametrically opposite to theirs. It may be worth while to step back and examine some of the basic premises around which the Austrian debate evolved.

The broad issue that both sides addressed from their opposite vantage points, was the relation of the self-regulating market system to the human community. From the Austrian perspective, the human community sprang fully formed from the constraints that governed the decision-making of the individual. The new science of «praxeology ${ }^{4}$, an account of how the individual made rational choices as the basis of human action, was proclaimed by von Mises with great fanfare. It established economic activity as one branch of the larger logical framework that he called «human action». As a prime example, such action was manifested in the process of market activity. This was done under the rubric of economic «scarcity» apparently, according to C. Menger, an existential condition of man's fate.

The Austrians approached the market as a construct of the mind. It emerged as the result of the natural exercise of rationality in making choices to allocate scarce goods among alternative uses. The market was thus synonymous with an outgrowth of clear (rational) thinking and contiguous in fact with human sanity itself.

F. von Hayek cast an even wider net. He saw the self-regulating market system as analogous to human biology and in particular to the process of homeostasis in the human body. He added a comparison with cybernetics and systems theory as well ${ }^{5}$.

3 L. Congdon, «The Sovereignty of Society: Polanyi in Vienna», in K. Polanyi-Levitt, ibid.,p. 82.

4 L. von Mises, Human Action, A Treatise on Economics, New Revised Edition, New Haven, Yake University Press, 1963, «Praxeology... [is human because it] claims for its theorems... universal validity for all human actions ... Human knowledge is constructed by the structure of the human mind» (p. 36).

s Hayek writes: « ... the old insight, well-known to economics, that our values and institutions are determined not simply by preceding causes but as part of a process of unconscious self-organization of a structure or pattern. This is true not only of economics, but in a wide area, and is well-known today in the biological sciences. This insight was only the first of a growing family of theories that account for the formation of complex structures... under various names such as autopoiesis, cybernetics, homeostasis... »

F. A. Hayek, The Fatal Conceit, The Errors of Socialism, W. W. Bartley III (ed.), Chicago, University of Chicago Press, 1988, p. 9; cf. also F. A. Hayek, Studies in Philosophy. Politics, and Economics, Routledge and Kegan Paul. London, 1967, p. 77. 
This ambitious framework designed to subsume the entire human economy, has its own interest for students of Polanyi for it established the challenge for his alternative vision of the economy. Polanyi's main theoretical essay, «The Economy as Instituted Process $»^{6}$, emerges as his refutation of the basic issues that the Austrians had originally posed.

The Austrian framework was designed to be theoretically «airtight»; that is, it was designed to explain all human behaviour that was not subject to misguided or irrational influences. It tied the individual with inexorable logic into the system of both market economy and market society. It was hardly possible to escape from this conceptual net to any alternative framework.

Universal scarcity necessarily compelled a logical pattern of choice at all times and places and this became the domain of economics. The ubiquitous link between economics and the economy led to the standard institutional response of market behaviour. Economic motives for the Austrians existed universally in their own right and were always compelling.

These were the main but implicit issues that Polanyi chose to address in his seminal essay «The Economy as Instituted Process $»^{7}$. The logic of rational action with regard to scarce means, the core premise of the Austrians Polanyi held, was socially conditioned, that is, based on a range of socially prescribed and acceptable choices rather than being an expression of a universal or 'sane' existence. Without such a prescribed set of choices as was offered in a monetized economy, there was no «economics». Austrian economics turned on a set of prescribed choices made systematically among given alternatives.

Polanyi held instead that a multitude of motives governed economic activity in history: none, except in the modern period, were purely «economic». Finally, by clearly identifying the non-market patterns of reciprocity and redistribution, Polanyi showed that these forms of integration were widespread historically and authentic economic patterns in their own right. These demonstrated forms of economic organization were alternatives to the market pattern. These were not ephemeral or irrational forms as the Austrians would have us believe. From his wider perspective on general economic history, Polanyi could thus sever once and for all the constraining link between economics - Austrian style - and the economy.

There was an additional dimension to the debate. The Austrians had regarded society itself as the outcome of the logic of human action, a pseudo-market institution writ large, that was based on exchange. Polanyi in turn posited a different vision of society, that of an active and independent protagonist that safeguarded the human community against the blind economic forays of the market system. This major drama of «Economy and Society» of the nineteenth century, was spelled out in detail in The Great Transformation $(G T)^{8}$.

6 K. Polanyi et al. (eds), Trade and Market in the Early Empire: Economics in History and Theory, New York, Free Press, 1957, p. 243-270. See also his article «our Obsolete Market Mentality », Commentary, vol. 3, n 2, 1947, p. 109-117.

K. Polanyi, op. cit.

$8 \quad$ Ibid., The Great Transformation: The Political and Economic Origins of Our Time, Boston, Beacon Press, 1944, 1957 and 1994. 
«Economy and Society» was the theme that remained at the forefront of Polanyi's theoretical concerns, but he underlined the variability of human institutions rather than these «inexorable loci»- the system of markets that governed market society.

While Polanyi's rebuttal of the Austrians was strategically effective and in our view, succeeded in neutralizing the grand Austrian apologia for the market paradigm, a basic problem remained. If the market did not emerge out of the very logic of human action as von Mises contended, how may we account for its origins? If the logic of «choice» was rejected, what alternative was there? Polanyi did go on to do sterling work in uncovering the non-market forms of integration as noted, namely reciprocity and redistribution. He followed this up with the analysis of the origins of trade and money as they arose independently of the market.

But what of the genesis of these patterns of the economic process? The problem can be stated as follows. Two of the three forms of integration operate within pre-existing social channels: reciprocity within symmetrical social structures such as twin tribes or kinship relations, and redistribution within a political hierarchy such as a tribal chief or king i.e. «centricity». These economic patterns are constrained by and emerge from these prior non-economic channels or institutions. What is missing from the Polanyi lexicon is a discussion of the corresponding factors that generate the market institutions - what may be called its «archaeology».

The market does not seem to emerge from any prior social or non-economic institutional channel. This is reflected further in Polanyi's notion of «embeddedness » in regard to the other two patterns, and in the «disembedded » nature of the market pattern. But the end result borders on tautology: the market pattern derives from market institutions. A conundrum exists in relation to the genesis of these market institutions and of the broader market pattern.

There would appear to be a gap in the Polanyi schema. What is needed to fill this gap is a functional alternative to the «praxeology» that the Austrians put forward. It is in this vein that we propose an «archaeology» of the market. This paper ventures into this area following along the structuralist approach employed by C. Lévi-Strauss in his exploration of the structure of myth. It draws as well on the Hegel-Marx concept of externalization («Ausserung») in the formation of human institutions.

\section{II}

Turning westward, from Vienna to Paris, we leave behind the discipline of the logic of human action and turn instead to those of sociology and anthropology: in particular, to structuralism as it developed in a broadly consistent line from E. Durkheim to R. Hertz, M. Mauss and C. Lévi-Strauss.

For E. Durkheim, all social institutions were «collective representations » of the structure of the mind'. But beyond that he said little about the genesis and emergence of such institutions. R. Hertz established the central role of polarities

E. Durkheim, Suicide: The Social Element of Suicide, Glencoe, The Free Press, 1951, p. 312. 
or binaries in his seminal essay on the right and left hand ${ }^{10}$. M. Mauss' remarkable essay on the gift played an important role in positing reciprocal behaviour as a key feature of human action ${ }^{11}$.

Lévi-Strauss set as one of his central tasks the outline of a universal «architecture of the mind $»^{12}$. Such a mind could not be discerned directly but only through its modes of expression. Myth seemed to be one such mode, a clear and immediate area in which to view the distinct imprint left by the mind.

The molecular element with which Lévi-Strauss worked was the binary pair, the constituent element of myth as well as of language that he had examined previously in his study of semiotics. Where tension existed between the two terms of the binary pair, new binary forms were generated as well as inversions. The insertion of a mediating agent between a sharply opposed binary pair was also common. All of these were regarded as vital clues in the pursuit of the elusive «architecture of the mind» to which Lévi-Strauss was committed. He was in fact remarkably successful in applying this method to the structure of myth.

But does this mode of analysis have anything to offer in the pursuit of a theory dealing with the genesis of the market institution? A qualified answer is offered here.

Two particular issues need to be addressed. First, in what way is the institution of the market (or any other form of integration for that matter) an expression of certain innate or ontological aspects of man? Despite the portrayal of the market as an inimical and artificial institution which is at the centre of Polanyi's work, what more can be said of the process by which markets arise? Can the questions the Austrians posed be resolved in a fashion that differs from their «universal $\operatorname{logic} »$ ?

Secondly, if we view the same broad issue from a more traditional angle, i.e. the Marx-Hegel concern with the phenomenon of «objectification» or externalization, can this approach be useful for those institutions that have acquired their own autonomous existence in modern society such as the market system?

\section{III}

The broad notion of human institutions as the projection of man's inner reality is not unique. For Hegel, social evolution consisted of just such a process of the emergence of the «inner» into the «outer», i.e. into the day-to-day institutional forms of society. Not surprisingly in The Economic and Philosophic Manuscripts of $1844(E P M)^{13}$, Marx echoed this theme as well, positing man's self expression as his «Ausserung» (or « outering») of his inner self. In the mists of an aboriginal stage in time, a natural or idyllic state may have existed where this self-expression

${ }^{10}$ R. Hertz, «The Pre-Eminence of the Right Hand», in R. Needham (ed.), Right and Left : Essays on Dual Symbolic Classification, Chicago, University of Chicago Press, 1973, p. 3-31.

11 M. Mauss, The Gift, London, Routledge Press, 1950.

12 C. Lévi-Strauss, From Honey to Ashes, London, Jonathan Cape Ltd, 1973, p. 473.

${ }_{13}$ K. Marx, The Economic and Philosophic Manuscripts of 1844, D. J. Struik (ed.), New York, International Publishers, 1964. 
flourished and took many forms. But the misappropriation of that self in capitalist society occurred subsequently through the process of alienation «Entausserung » (These two latter terms in German stood in binary tension).

Most of Marx' attention was taken up with «Entausserung» or alienation; he gave little thought to the prior proposition, the process of externalization itself. How in fact did man embody himself not only in his artifacts but in the social institutions that expressed his person, his goals and his aspirations? Capitalism (or the market system) was treated by him as a form of subversion of man's human capacities and of his authentic forms of self-expression. This was regarded as a necessary stage of historical development through which man had to pass. For Marx, the momentum of these inner contradictions of the social process, produced the forces of its own eventual destruction. The next phase of development emerged in the process of transcending these contradictions. But the pendulum of this dialectic « overshot» with virtually every «swing», and the authenticity of the social process as a form of man's inner self-expression was distorted.

The Hegel-Marx notion of «objectification» and «externalization» can thus be used as a starting point or probe for examining a range of transformative social processes but offers few subsequent guidelines to how these processes develop (The same is true of Lévi-Strauss' structural approach).

What was required for Marx was a negation of tainted forms of social existence; this comprised virtually all of history. Man could hardly recognize the original, pristine elements of his being and personality any more in the corrupted «externalization» of the social processes that now surrounded him.

The institution of the market was for Marx, an alien expression of man's social existence, a misappropriation of man's creative output. But few were inclined to ask the prior question of whether, man's institutional forms - including the market - were manifestations, genuine or distorted, of some initial inner reality. The elements of that inner reality however, remained extremely vague.

As far as Polanyi was concerned he used binary concepts and forms of expression with great effectiveness as a natural feature of his own writing style. The structures of the $G T$ for example, are a prime example of the powerful use of binary forms in establishing Polanyi's compelling argument about market society. The rhetoric of the GT unfolds as a tale of strict binaries : market and non-market, embedded and disembedded, real vs. «fictitious » commodities and so on.

But beyond this rhetorical mode lay the heart of the social reality that Polanyi conveyed in his portrayal of the «double movement» of nineteenth century capitalism. We are dealing here with the powerful forces that brought down the nineteenth-century work of liberal society and resulted in the Great Depression and chaos of the 1930s (outlined in the G.T.)

Here the great «binary » came alive with a vengeance: the inexorable march of the self-regulating market system encountered the spontaneous resistance of the constituent elements of society: labour and land. Like Marx and indeed Hegel, Polanyi described the world dramatically in terms of these polarities, these great contradictions. These social forces in binary opposition - the market economy versus society - had actually acquired a momentum of their own.

All this had helped to make the $G T$ a compelling portrait of the contradictory social forces that were at work in the nineteenth and twentieth centuries. But it necessarily renders more complex the broad question we have posed. Even if the 
genesis of social institutions such as the market can be linked to some manifestation of the mind, the social history of that institution may subsequently take on a life of its own beyond the original parameters within which it was conceived. In short, the genesis of the institution (unlike the approach taken by the Austrians) does not foretell much about the future social role that it may play nor about the criss-crossing social processes that may be initiated by its existence.

The contemporary struggle was against the blind, impersonal forces that had been unleashed by the initial interaction of machine and man. Such further developments are neither predictable nor follow from the previous projection of mind phenomena. Institutions in short, are not a static replica of the logical categories of the human mind. Once initiated, they take on a life of their own, and may generate corresponding countermeasures of social policy. In contradistinction with the approach of the Austrian economists, institutions may begin to operate at several removes from the original structure of the mind.

Polanyi shared Marx' vision of authentic human community but gave that community a more dynamic role. This formed the centerpiece of the $G T$, namely the dynamic tension of Polanyi's «double movement». A society that had been put in jeopardy by the market, rallies in self-defence through a countermovement intended to impede the 'steamroller' of the self-regulating market economy. Marx' dialectic of the inner contradictions of the capitalist system was thus transmuted into Polanyi's «double movement», into a fateful tension between economy and society. Hence for both Marx and Polanyi, the initial manner of man's «Ausserung », the outward expression of his humanity and inner being had been superseded by the contemporary social struggle against an externalization that had gone wrong.

In a perverse and runaway fashion something had gone awry with the «normal» expression of man's humanity. For Polanyi the economy was «disembedded» from society, or perhaps, disembodied. Although markets had been present intermittently from at least the time of the Ancient Greeks, they had never coalesced into a market system Polanyi argued, nor had the factors of production, labour and land been brought under the sway of the market.

The contemporary struggle he maintained, was against the blind impersonal forces that had been unleashed by the initial interaction of man and machine. These further developments were neither predictable nor linked to the previous projection of mind phenomena. In short, they were not a static replica of the logical categories of the human mind. Once initiated, institutions such as the market system took on a life of their own and invoked in turn the appropriate countermeasures of social policy. In contradistinction to the approach of the Austrian economists, the justification and legitimation of the market system no longer was a function of the structures of the mind nor of the logical propositions that emanated from it. Institutions such as the market system took on a direction of their own,

Polanyi's argument was the following: Once man had decided to use elaborate and expensive machinery in the process of production (for seemingly exogenous reasons), he had to assure a steady flow of inputs - both raw materials and labour - to make these investments pay. At that time only the market system could bring this about, and it seemed therefore to be a matter of pragmatic necessity.

The advent of the market system thus appears as an adjunct in Polanyi's way of thinking, to the coming of the industrial revolution - a peculiar and contingent 
outgrowth of individual markets and discrete systems of markets in the time of the machine.

\section{IV}

One of Polanyi's most original contributions as noted, was the positing of the forms of integration as the basic patterns of economic activity. He was able to reduce all patterns of human economic activity to three possible forms: reciprocity, redistribution, and the market. Reciprocity, for example, is the offshoot of a prior symmetrical structure, a channel within which the pattern operates. Some simple phrases sum up the process such as «quid pro quo», and «give-and-take». The ubiquity of symmetrical structures in human society account for the widespread existence of this pattern. Reciprocity encompasses the notion that one set of actions should evoke an equivalent but appropriate response and this may occur in areas far outside economic life. The same deeply rooted principles lie behind the «lex talionis» (the «eye for an eye»), or the payment of «wergild» among the early Germanic tribes as compensation for injury or murder. Symbolically, justice is depicted with a blindfold holding up the scales where equals are balanced against equals as the inherent expression of what is right.

Whether the issue is revenge, justice, or merely the give-and-take of everyday life, one senses that the notion of reciprocity has ontological roots deep in the structure of the human psyche.

Polanyi had emphasized that reciprocity could occur only if there were a prior structure or relationship of «symmetry». The gift-countergift and the related activities of economic reciprocity take their place in this broader context of a human structure or code of behaviour that sets out the nature of the response that is expected. The sense of give-and-take under reciprocity is not subject to precise quantification but to a shared (internalized) understanding of what is appropriate in this reciprocal movement.

Redistribution in turn falls back on the existence of a recognized political authority figure within the group or society in question («centricity»). The movement of goods to a center, and out again, embodies some entrenched notions of hierarchy as well as responsibility between the two levels. But the authority in question (chief, feudal lord etc.) «integrates» i.e. allocates the movement of goods within channels that are essentially political and legal. Once again, a wider context is suggested - the existence of power as a universal phenomenon in human society. A power center (centricity) integrates those movements that make for the order and stability of the structure.

What is offered and received under reciprocity and redistribution is defined by several possible factors such as the status of the participants, the nature of the situation, and whatever special qualities may inhere in the good itself that is changing hands.

This leaves us with the third form of integration and our immediate subject, the market. As a form of integration the market pattern differs from the other two insofar as it is not embedded - that is, it does not operate within the social channels of a prior non-market institution. It requires instead a legally sanctioned market that is formally established or recognized. 
At first glance, the market is a radical rupture with the other two forms of integration. Instead of being marshalled by social or political obligations, the participants in the market operate (by definition) entirely on a voluntary basis and have an arm's-length relationship to each other. All personal or political ties have (in principle) been surgically severed or at least suspended for the duration of the transaction. Yet if we explore more closely what transpires in a market transaction, we find beneath the surface, strong residual echoes of both reciprocity and redistribution in derivative or functionally equivalent forms.

The day-to-day activities of going to market may seem so commonplace and routine as not to merit an extended, much less an ontological exploration. What could be more ordinary and obvious than buying or selling in the market? These facts of everyday life are congenial and seemingly self-evident. But that merely disguises their ontological roots and their kinship with other manifestations of the mind.

Market activity in its pristine form is a ritualized drama. It may begin with casual greetings and social pleasantries, yet at some point the two participants slip into the typical roles of buyer and seller during a transaction. The main feature of this core relationship is the latent antagonism between the two - insofar as the buyer succeeds in his main objective of buying as cheaply as possible, it is at the expense of this seller who wishes to do the opposite, i.e. to sell as dearly as possible. It is this core relationship of buyer/seller that creates the molecular element at the heart of Lévi-Strauss' analysis: namely, the tension of the basic binary pair. This binary is the foundation of the structuralism derived from his earlier exploration of such binary elements in semiotics and carried further in his analysis of myth (His «mythologiques» translates best as the «logic of myth»). The standard graph of the supply and demand curves in economics, reveals each curve (broadly) as being a mirror image of the other, an extended representation of a series of binary pairs in graphic form.

Money acts as a «mediator» (in Lévi-Strauss' language) within the binary of buyer and seller. It also permits the introduction of the new elements of quantification and precision through the operation of prices. An agreed price serves as the point of resolution of the binary tension between buyer and seller. It transforms the original latent antagonism of the two into the functional equivalent or proxy for a reciprocal relationship. Instead of the usual features of reciprocity, where the appropriate rules of exchange have been internalized as the «quid pro quo » of custom or tradition, an external device (money) serves as a proxy for the basic norm that must be fulfilled, that equals must be exchanged for equals in a verifiable, objective way.

The operative point is that the older internalized norms that establish equality have been externalized and quantified to establish precision. With the assistance of money and prices, equals continue to be exchanged for equals and the ratification of the «quid pro quo» under these new arrangements is complete and verifiable.

The market rested not only on these derivative elements of reciprocity but on some elements of redistribution as well. The market system integrates (in principle) a complex network of the division of labour. When the market acts as the «invisible hand» it becomes the focal point at which decentralized activities of production are integrated into a larger economy. In that sense the market acts, at 
least nominally, as a «center». It performs the functional equivalent of directing the flow of goods into a center and out of it again. Each individual contributes and receives as if he were dealing directly with some authority (centricity) who is (in principle) «invisible».

This tentative exercise in «deconstruction» of the market thus uncovers its role as a synthetic institution adapted to the new external social parameters. In this sense, the market recasts or synthesizes elements of the other two forms of integration under new conditions. It provides functional alternatives to the structural elements of symmetry as well as centricity. The market exists however as an externalized form of these structures and activities, detached from the interpersonal bonds of society. It is the dissolution of these interpersonal bonds in the societies with large populations, with the new norms of «atomistic individualism», with more extensive division of labour, and the demands of individual production that force such a change in economic organization.

The synthetic institution of the market is not simply a benign alternative. Once created, the market gives rise to new and unexpected phenomena such as the autonomous network that is the self-regulating market system. This system acquires inadvertently an independent runaway existence.

This structural approach to the market bypasses the question of its historical development, including the issue of «stages ». The larger methodological issue is the synthesis of structural or ontological elements and institutional systems. The resultant «hybrid» is not merely the sums of its parts. The synthesis has added a new and unexpected dimension, thus sponsoring a further process of institutional change. Here we may have to part company from Lévi-Strauss' «the architecture of the mind » and address a different process - that of institutional artifice, ingenuity and indeed unpredictability in the evolution and proliferation of social systems detached from their ontological roots.

\section{V}

This attempt to «deconstruct» the market has tried to separate its constituent elements: what is continuous from previous economic patterns and what is novel. But the market system - by which we mean the entire integrated network of a capitalist system - contrary to the Austrians' view, did not spring fully formed from the «rational» elements of the mind. Nor is there more than a superficial similarity in its origins to biological systems such as homeostasis nor the feed-back loops and computer models of cybernetics.

We may share with the Austrians the view that ontological elements of mind structure are present in the genesis of the market but which? The rationality of choice among scarce means is overtly at work here as a guiding norm of the market place. But we must also recognize the symbiosis of quite different institutional arrangements unconnected with the logic of rational action. The element of «reciprocity», illustrated by the ontological roots of the «gift», speaks to the abiding norm of «equals for equals». This phenomenon is deeply ingrained but not readily acknowledged as the basis of «human action». Through the use of money and prices we have objective verification that «equals » are exchanged for « equals » (since every commodity has its own price). It is a synthetic equality, but 
even those who challenge its legitimacy (as in the Marxist tradition) share the belief that (genuine) equality is the desirable standard for human interaction.

These two norms of rationality and reciprocity are yoked together in the market transaction. But in their uneasy coexistence we have the ongoing tension between «efficiency» (rational allocation) and «equality» (reciprocity). This tension informs the basic issues of our debates on social policy.

Such ontological features convey legitimacy to market institutions and may help to explain the dynamic nature of their diffusion. «Equals for equals » as noted earlier, underlies the popular acceptance and mandate of the market system. Of course this was also the premise that Marx claimed had never been achieved. But even his brilliant indignation was an implicit tribute to the importance of this ontological premise both in its breach and its observance.

The interweaving of ontology, technology, and institutions occurs in ever more complex ways. Major disruptions of traditional patterns result from such factors as population growth, migration, and urbanization, taking their toll on established institutions. «Symmetry» and «centricity» are weakened and displaced by some functional equivalent. What is notable amid this synthetic recreation of new institutions is, as we have seen, the retention of some vital elements of the old. We may thus be able to account in some small way for the global resurgence of market systems today in unexpected places.

Professor Emeritus

Economics and Political Science

University of Toronto

abraham.rotstein@utoronto.ca

\section{BIBLIOGRAPHY}

E. Durkheim, Suicide: The Social Element of Suicide, G. Simpson (ed.), Glencoe, The Free Press, 1951.

F. A. Hayek, The Fatal Conceit, The Errors of Socialism, W.W. Bartley III (ed.), Vol. 1, Chicago, University of Chicago Press, 1988.

- Studies in Philosophy. Politics, and Economics, London, Routledge and Kegan Paul, 1967.

R. Hertz, «The Pre-Eminence of the Right Hand», Right and Left : Essays on the Dual Symbolic Classification, R. Needham (ed.), Chicago, University of Chicago Press, 1973, p. 3-31.

K. Marx, The Economic and Philosophic Manuscripts of 1844, D. J. Struik (ed.), New York, International Publishers, 1964.

M. Mauss, The Gift (trans.), W. D. Halls, London, Routledge Press, 1950.

K. Polanyi, The Great Transformation: The Political and Economic Origins of Our Time, Boston, Beacon Press, 1944.

K. Polanyi et al. (eds), Trade and Market in the Early Empires: Economies in History and Theory, New York, The Free Press, 1957

L. von Mises, Human Action, A Treatise on Economics (new revised Edition), New Haven, Yale University Press, 1963. 